\title{
Induced Changes in Reserve Materials in Evergreen Herbaceous Leaves.
}

\author{
BY \\ GWYNETHE M. TUTTIE, M.Sc., \\ Bolanical Department, University of Alberta. \\ With seven Figures in the Text.
}

FVERGREEN treès are generally divided into two classes: (a) 'starch'

E trees, whose reserve food is stored in the form of starch, and $(b)$ ' fat' trees, in which the starch is converted into oil during the autumn. According to Warming (1), the presence of oils and fats in the latter may enable the plant to withstand lower temperatures, 'in that fatty oil in the form of an emulsion prevents the sub-cooling of the plant tissue and increases the power of "resistance to frost'. Hence 'we find this class of trees largely distributed throughout the colder regions, while the 'starch' trees are found in localities of higher winter temperature.

Much attention has been given to this phenomenon in trees, but no information is available in connexion with herbaceous plants. Since many evergreen herbaceous plants grow in the shade of the 'fat' trees subjected to the same extremes of cold, it would seem possible that they should exhibit similar features. It was with a view to ascertaining a few facts in this connexion that the present.work was undertaken. My attention was called to the need for investigation in this direction by Dr. F. J. Lewis, to whom I am greatly indebtèd for helpful criticism and suggestions given throughout the progress of the work.

The only recent investigation bearing on this subject is that of Küchi Miyake (2) at Tokyo. He confined his attention solely to the calculation of the winter starch content of a number of trees and herbaceous plants from different parts of Japan. The conclusion is reached that the starch content of trees in winter is very small compared with that during the summer, but that the content varied with trees of different species and also with the region from which the matcrial came-that from Northern Japan,

[Annals of Botany, Vol XXXIII. No. CXXX. April, 1919.]

Q 2 
where lower winter temperatures occurred, showed less starch than that from the southern districts. Küchi Miyake simply recorded the starch content as he found it. He did not try to account for its variation. It would have been interesting to know whether part of this decrease in starch was due to the formation of fats and oils at the beginning of winter, but 10 mention is made of investigation in this direction.

The present investigation was undertaken, therefore, not so much with a view to ascertaining the food reserve in a large number of plants as that of a single one, Linnaea borealis, L. var. Americana, Forbes, and to investigate the changes which these reserves undergo when subjected to different temperature conditions.

In view of the fact that temperature is vitally connected with the problem, a brief statement may be given of the meteorological conditions of the district. Early frosts are characteristic of Western Canada, occurring usually from the 6th to the Ioth of September-frequently followed by warmer periods. The precipitation during September and October is usually high, but varies considerably with the different years. The winter seasons are quite variable, but the extreme temperatures remain the same from year to year, ranging from about $-40^{\circ} \mathrm{F} .\left(-40^{\circ} \mathrm{C}\right.$.) to an occasional $50^{\circ} \mathrm{F} .\left(10^{\circ} \mathrm{C}\right.$.). The humidity of the air is moderately low and high winds are rare. The depth of snow averages from one to two feet on the level.

The winter 1916-17, however, has been unusual. Cold periods of five to ten days in which the thermometer ranged from $0^{\circ} \mathrm{F} .\left(-17^{\circ} \mathrm{C}\right.$.) to $-40^{\circ} \mathrm{F} .\left(-40^{\circ} \mathrm{C}\right.$.) have alternated quite regularly with slightly longer periods of rising temperature, reaching on one occasion $47^{\circ} \mathrm{F} .\left(8^{\circ} \mathrm{C}\right.$.). As will be mentioned later, these fluctuations have been useful during the progress of the investigation, especially in connexion with reconversion.

\section{Preliminary Tests of Reserves.}

The work was commenced late in October, just about the time of leaffall of deciduous trees. A number of leaves were examined then for their starch and oil content. A solution of iodine and another of chloral hydrate and iodine were used in the tests for starch, the former in the preliminary tests and the latter in the material during conversion, as the chloral hydrate swelled the starch grains and also decolorized the sections, thus making the reaction much clearer. For fats and oils, sections of the material were tested with a I per cent. solution of osmic acid and also with neutral red solution, both tests yie!ding similar results.

Table I shows the starch and oil content of the majority of local plants which still retained their leaves. 
TABLE I.

Fall Starch and Oil Content of Leaves.

\begin{tabular}{|c|c|c|c|}
\hline $\begin{array}{l}\text { Date. } \\
\text { Oct. } 23\end{array}$ & $\begin{array}{l}\text { Material. } \\
\text {. }\end{array}$ & Starch. & $\begin{array}{l}\text { Oils and Fats: } \\
\text { Large amount }\end{array}$ \\
\hline Oct. 23 & $\begin{array}{l}\text { Picea canadensis, Mill (B.S. P.) } \\
\text { Pyrola rotundifolia, L. }\end{array}$ & Very little & Large ą \\
\hline $\begin{array}{ll}\Rightarrow 23 \\
" \quad 23\end{array}$ & Pyrola rotundifolia, L. & $\begin{array}{l}\text { None } \\
\text { Very little }\end{array}$ & ", \\
\hline $\begin{array}{ll}\Rightarrow & 24 \\
\Rightarrow & 26 \\
" & 26\end{array}$ & $\begin{array}{l}\text { Cornus canadensis, } \mathrm{L} . \\
\text { Hypnum (sp.) } \\
\text { Marchantia (sp.) }\end{array}$ & $\begin{array}{l}\text { None } \\
\text { Good reaction } \\
\text { Very little }\end{array}$ & $\begin{array}{l}\text { None } \\
\text { Large am }\end{array}$ \\
\hline $\begin{array}{ll}\Rightarrow & 26 \\
, & 28\end{array}$ & $\begin{array}{l}\text { Mitella nuda, L. } \\
\text { Pinzes Banksiana (Lamb) }\end{array}$ & $\begin{array}{l}\text { None } \\
\text { Very little }\end{array}$ & $"$ \\
\hline
\end{tabular}

It will be seen from the table that all the evergreens were practically destarchified, and on the other hand they contained a large amount of oil.

\section{iI. Conversion of Oils and Fats to Starch.}

A series of experiments was then started to induce the formation of starch in the destarched plants. The following plants were brought indoors and subjected to higher temperatures : Linnaea, Pyrola, and Picea. The first two plants were potted, but in the case of Picea shoots were kept in water. The experiments were kept in a dark room at a temperature of $68^{\circ} \mathrm{F}$. $\left(20^{\circ} \mathrm{C}\right.$.), and in each case a control was placed outside in the dark at the lower temperature.

The material of Linnaea showed starch appearing as early as the second day, while Pyrola and Picea showed no increase, although allowed to remain at the higher temperature for five weeks. This points to the fact that different species vary in their response to the change in temperature.

As Linnaed responded most readily to experiment, the following observations were all made from that plant. They are based on material collected and potted at intervals of five or six days during November and December, 1916, and January, 1917. In each case the result was based on a test from six to twelve leaves.

TABLE II.

Starch in Material exposed to Highier Temperature. Condition
zuhen potted.

No starch No test

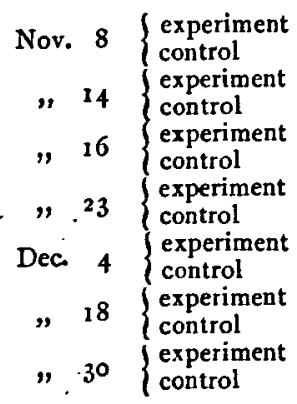

ist day.

$$
\text { 2nd day. }
$$

No test

",

,"

,

",

,

No" starch

Slight reaction

No reaction

Slight reaction

No reaction

Slight reaction

No reaction zrd day. $4^{t h} d a y$.

$I$ week.

No test
Good reaction
No starch
No test
",
",
",
",
",

No test " ",

Good reaction No starch Good reaction No starch

Good reaction No starch

Good reaction No starch Good reaction No reaction
Good reaction No starch Strong reaction No starch

Strong reaction No starch Strong reaction No starch Strong reaction No starch Strong reaction No starch Strong reaction No reaction 
Material which has been inside for two days shows a starch reaction in all parts of the leaf. At the end of four days the cells are quite crowded with starch, but the amount increases until the seventh or eighth day (Fig. 1), after which time the starch content seems to remain constant.

The starch in all cells is present in a very finely divided state and the individual grains exhibit Brownian movement to a marked degree.



FIG. 1. Cross-section of Linnaea leaf, showing starch in material exposed to higher temperature for one week. Section treated with chloral hydrate and iodine.

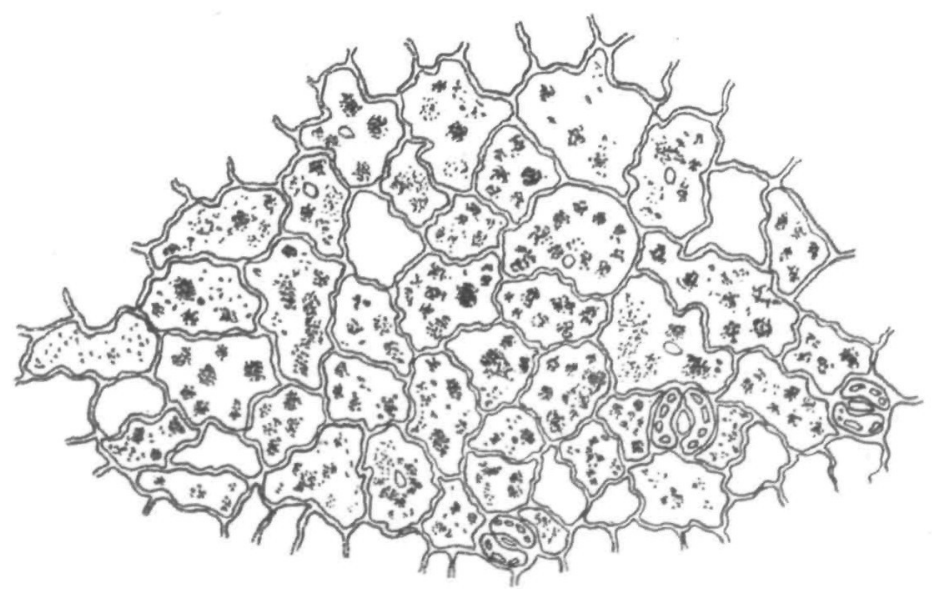

FIG. 2. Horizontal section of Linnaea leaf, showing starch in epidermal cells. The material had been exposed to higher temperature for one week. Section treated with chloral hydrate and iodine.

It is interesting to note the large amount of starch present in the epidermal cells of material undergoing conversion (Fig. 2), as none is found . there during the summer when the starch is being formed as a product of photosynthesis-this apparently suggesting that the starch has arisen by conversion of oils and fats which are abundant in the epidermis during the 
winter (Fig. 3). It has been observed that the starch grains are grouped as though each group had arisen from a single oil globule.

No regular variation in the conversion has been determined. Entire plants have been tested, and it has been shown that they do not possess ' fat'. leaves and 'starch' leaves-all leaves tend to form starch when exposed to higher temperature. Fig. 4 shows the test of three plants from material which had been exposed to higher temperature for four days.

In this test, plants I and. III gave a strong reaction in all of the leaves, but very little reaction was obtained in any leaves from plant II.

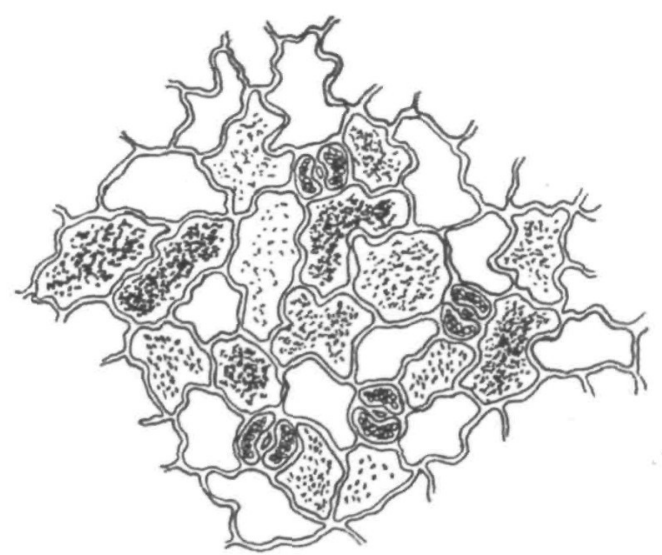

FIG. 3. Horizontal section of Limaea leaf, showing oils and fats in epidermal cells. Material fresh from outside before exposure to higher temperature. Section treated with 1 per cent. osmic acid.



Plant I.

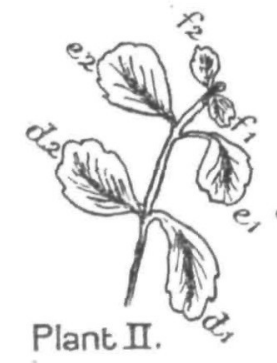

Plant II.

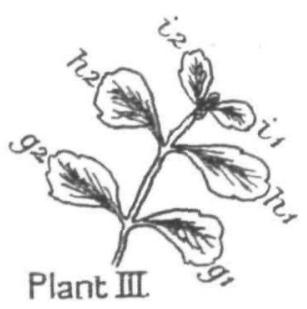

FIG. 4. Linnaea material exposed to higher temperature for four days, sections of which were treated with chloral hydrate and iodine.

Strong starch reaction in sections from $a_{1}-a_{2}-b_{1}-b_{2}-c_{2}, g_{1}-g_{2}-h_{1}-h_{2}-i_{1}-i_{2}$.

Slight starch reaction in sections from $e_{1}-f_{2}$.

No " " " " " $\quad e_{2}-d_{1}-d_{2}$. .

This may be due to the fact that its leaves were not so vigorous as those of plants I and III. Hence any variation seems to be due to some plants being more vigorous than others, and also to the age of the leaves, as it has been observed that younger leaves carry on the conversion much more rapidly than do the older ones. 
The increase in the starch content of these leaves is much more evident than the decrease in the oils and fats which one would suppose must be taking place, as that seems the only source from which the starch can be derived, for the factor of photosynthesis has been eliminated by placing the material in darkness. All the leaves showing a large amount of starch gave a strong reaction with the test for oils and fats. In horizontal sections passing through the epidermis there scems to be quite as much oil as.starch present. The palisade tissue shows no appreciable decrease. It is only in the cells of the mesophyll that an actual difference has been recognized. .Here the decrease is quite evident, as will be seen by comparing Figs. 5 and 6 .

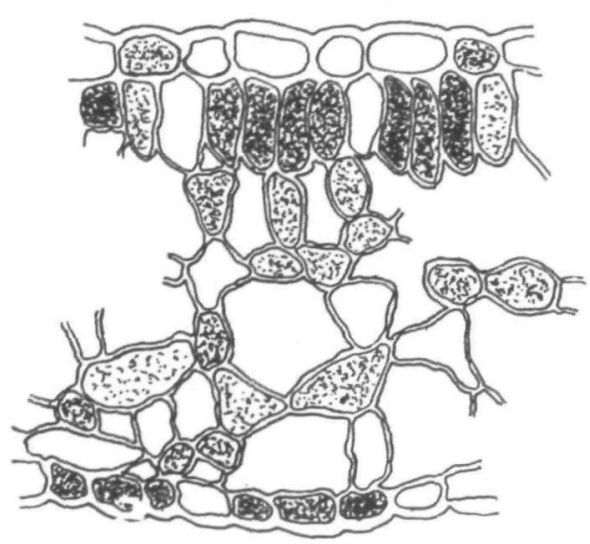

Fig. 5. Cross-section of Linnaea leaf, showing fats and oils before exposure to higher temperature. Section treated with I per cent. osmic acid.



FIG. 6. Cross-section of Linnaea leaf, showing decreased fat and oil content. Material exposed to higher temperature for one week. Section treated with I per cent. osmic acid.

\section{Reconversion of Starch into Fats and Oils.}

Having shown that starch appears in those leaves subjected to a higher temperature, it was then attempted to cause a reconversion of the starch to oils and fats by lowering the temperature. Material of Linnaea which had been kept at $68^{\circ} \mathrm{F} .\left(20^{\circ} \mathrm{C}\right.$.) for a week, and which showed as a result a high starch content, was placed outside in darkness on two different datesNovember 25 and December ${ }^{3} 3$. As will be seen from Tables III and IV, the temperature conditions were very different during the two experiments.

TABLE III.

Material containing Starch exposed to moderately low Temperature.

\begin{tabular}{|c|c|c|c|}
\hline Date. & $\begin{array}{c}\text { Av. } \\
\text { Tenperalure. }\end{array}$ & Experiment. & Control. \\
\hline Nov. $\mathbf{2 5}$ & ${ }^{2} 5^{\circ} \mathrm{F} .\left(-3^{\circ} \mathrm{C}.\right)$ & Strong starch reaction & Strong starch reaction \\
\hline $\begin{array}{l}\because 30 \\
\text { Dec. } 4\end{array}$ & $\begin{array}{l}36^{\circ} \mathrm{F} \cdot\left(3^{\circ} \mathrm{C} .\right) \\
2 \mathrm{~S}^{\circ} \mathrm{F} .\left(-2^{\circ} \mathrm{C} .\right)\end{array}$ & $\begin{array}{l}\text { Decreased starch content, four } \\
\text { leaves ont of six destarchified } \\
\text { All material destarchified }\end{array}$ & $"$ \\
\hline
\end{tabular}


TABLE IV.

Material containing Starch exposed to extremely low Temperature.

\begin{tabular}{|c|c|c|c|}
\hline Dale. & $\begin{array}{c}\text { Av. } \\
\text { Temperature. }\end{array}$ & Experiment. & Control. \\
\hline & $4^{\circ} \mathrm{F} .\left(-15^{\circ} \mathrm{C}.\right)$ & Strong starch reaction & Strong starch reaction \\
\hline 20 & $-16^{\circ} \mathrm{F} \cdot\left(-26^{\circ} \mathrm{C}.\right)$ & $\begin{array}{l}\text { No decrease in starch, cells } \\
\text { strongly plasmolysed }\end{array}$ & $"$ \\
\hline 23 & $-19^{\circ} \mathrm{F} .\left(-28^{\circ} \mathrm{C}.\right)$ &  & " \\
\hline
\end{tabular}

From Tables III and IV it is seen that material containing a large amount of starch undergoes reconversion, in which the starch is changed back into oils and fats if subjected to moderately low temperature. If, however, the material, full of starch and hence in a summer condition, is subjected to extremely low temperatures no reconversion takes place and the material is killed. The strong plasmolysis of the cell contents exhibited in this material is shown in Fig. 7 .

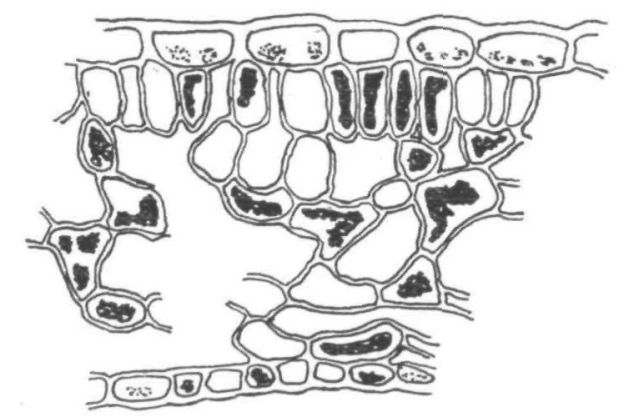

FIG. 7. Cross-section of Linnaea leaf. Material outside for reconversion during extremely low temperature. Section treated with iodine solution. Starch grains visible in epidermic cells. Owing to the high starch content, the plasmolysed cell contents were stained deep blue.

\section{Cause of Conversion.}

The conversion of fats to starch is quite impossible as an unaided chemical change, and hence the action of, an enzyme is suggested. Tests were made for the presence of an enzyme both in material fresh from outside and in that which had been exposed to higher temperature for some time.

The test in this case was an alcoholic solution of guaiacum resin, which, with the addition of hydrogen peroxide, gives a blue reaction in the presence of any enzyme. In enzyme tests made December 7 and 18 in fresh material no reaction was obtained. Material, however, which had been exposed to higher temperature for several days gave a strong reaction when tested.

About a month later (Jan. II-I6) material in the same condition was tested which yielded rather different results. In the interval, however, the weather had moderated and some very high temperatures had been recorded. All Linnaea leaves, both from outside and inside, then responded very strongly to the enzyme test. There was an inclination at first to doubt the test, but when leaves of Begonia and Geranium from a greenhouse gave negative results it was concluded that the change in temperature must have affected the outside material. Still the change had not been great enough to 
cause the formation of starch, for the outside material gave no reaction to the iodine test. The effect of changing temperature was watched, and it was found that the enzyme response diminished after a fortnight of lower temperature, although at that time a slight reaction was given despite the fact that the material was gathered when the temperature was lower than $0^{\circ} \mathrm{F} .\left(-17^{\circ} \mathrm{C}\right.$.).

The important point, however, was that the material undergoing con-. version gave a strong enzyme reaction. The next step was to determine whether or not this was due to the fat-splitting enzyme lipase. The test applied was that used by G. J. Fowler (3) and Reynolds Green (4) in work with germinating Ricinus seeds. Here the solution which is to be tested for the presence of the enzyme is allowed to act on an oil emulsion causing (if lipase be present) the hydrolysis of the oil and the formation of a fatty acid.

An extract of the leaves was made by grinding them in a mortar with a solution containing 5 per cent. sodium chloride and 0.2 per cent. thymal as an antiseptic. This was allowed to stand for twenty-four hours and then filtered. The filtrate was treated as follows : an emulsion of olive oil with a little gum arabic was made, and to this was added a small amount of the extract, phenolphthalein being used as an indicator. As the leaf extract and oil emulsion were both slightly acid, they were carefully neutralized with a few drops of very dilute caustic potash. From two to five experiment tubes were made up in this manner. A control was made up in a similar manner, except that the extract was boiled for two or three minutes before it was added to the emulsion. Both experiments and control were placed in an oven at $95^{\circ} \mathrm{F} .\left(35^{\circ} \mathrm{C}\right.$.). Table $\mathrm{V}$ gives the results of several tests for lipase in extracts from material of different conditions. The test made on January 9 shows that fresh material from outside without exposure to higher temperature does not respond to the test for lipase.

TABLE V.

Action of Lipase.

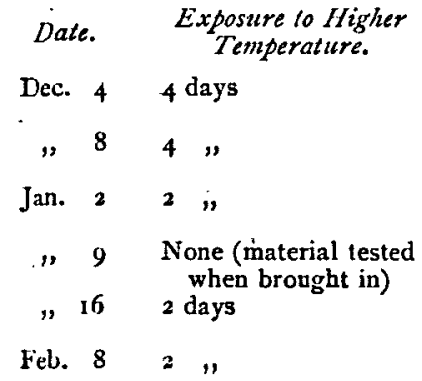

Experiment.

Acid reaction after 4 hours

Acid reaction after 4 hours

Acid reaction after 2 hours

No reaction

Acid reaction after 2 hours

Acid reaction after 4 hours
Boiled
Control.

No reaction

" Phenolphthalein

,

,

Slightly acid ${ }^{1}$

No reaction
Indicalor.

Litmus

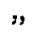

"

,

,

1 Due to insufficient boiling. 
It has been recorded earlier in the paper that material fresh from outside responded to the general enzyme test. Experiment of January 9 in Table $\mathrm{V}$ shows that the enzyme in fresh material is not lipase-hence the presence of another enzyme is suggested. Owing to the browning of the leaf extract on standing, oxidases were suggested.

It was determined (3) that guaiacum resin without the hydrogen peroxide was a test for oxidase alone, and so the material was subjected to this test. Sections of the leaves, both fresh and converting, gave only slight reactions with the guiacum resin, but the extract gave a good response. This is due to the fact that, on standing, a substance is formed in the extract which increases the oxidation (5).

In the tests for lipase given above it will be noticed that phenolphthalein was used as an indicator instead of the litmus solution used by Reynolds Green in his experiments with extract from endosperms of Ricinus. Litmus was used in the early experiments in this work, but it was found that the plant extract decolorized the litmus directly it was added. This fact was a further proof of the presence of oxidases, as they cause an immediate decolorization of litmus solution. Hence litmus was of no use as an indicator in the presence of oxidases, and so phenolphthalein was substituted, with whose action they do not seem to interfere.

The results of this investigation may be briefly summarized as follows:

1. Most evergreen plants are destarchified in NW. Canada as early as October, and then contain a large amount of oil.

2. Exposure to higher temperature in the case of Linnaea induces the formation of starch in darkness.

3. Starch is present in the material after two days and increases in amount until about the eighth day.

4. The starch is in a very finely divided state and the individual grains exhibit Brownian movement.

5. All healthy leaves are capable of carrying on conversion. The plant does not possess ' starch' leaves and 'fat' leaves.

6. The starch disappears when again exposed to moderately low temperature for about eight days, but the leaves are killed if exposed to extremely low temperatures when filled with starch.

7. A decrease in the oil content is evident in leaves which have formed starch by conversion.

8. Enzymes are present in material undergoing conversion.

9. Lipase has been demonstrated in material undergoing conversion.

10. Oxidases are present in the leaf of Linnáea even at quite low temperature. 
210 Tuttle.-Induced Changes in Evergreen Herbaceous Leares.

\section{BIBLIOGRAPHY.}

1. WARMing, Eug.: Ecology of Plants. 1909.

2. Küch I MiYaKe: On the Starch of Evergreen Leaves and its Relation to Photosynthesis during the Winter. Bot. Gaz., xxxiii.

8. Fowler, G. J.: Bacteriological and Enzyme Chemistry. I9II.

4. Reynolds Green, J. : Fermentation. Igor.

5. Wheldale, Muriel : Direct Guaiacum Reaction given by Plant Extracts. Proc. Royal Society, Series B, 84. 